\title{
THE MOSS MACROMITRIUM RICHARDII (ORTHOTRICHACEAE) WITH SPOROPHYTE AND CALYPTRA ENCLOSED IN HYMENAEA RESIN FROM THE DOMINICAN REPUBLIC
}

\author{
JOCHEN HEINRICHS, DALE H. VITT, ALFONS SCHÄFER-VERWIMP, \\ EugENiO RAGAZZI, GIOVANNI MARZARO, DAVID A. GRIMALDI, \\ Paul C. Nascimbene, Kathrin Feldberg \& AleXAnder R. SchmidT
}

\begin{abstract}
Dominican amber is an important source for Early Miocene bryophytes. We report the moss Macromitrium richardii Schwägr., an extant representative of the Orthotrichaceae, from the Dominican amber collection of the American Museum of Natural History. This species is currently a widespread Neotropical epiphyte. The specimen includes several gametophytes and sporophytes, and represents the first fossil record of Orthotrichaceae. Alongside the Macromitrium shoots we observed several fragments of the liverworts Cheilolejeunea antiqua and Frullania sp. The unusual thermal behavior of the resin sample initially led to doubts about the Miocene age of the specimen, but chemical analyses of the Hymenaea resin provides evidence that the specimen represents a highly oxidized sample of Miocene Dominican amber rather than an artificially thermally-treated subfossil resin (copal). Our inclusion demonstrates the exceptional preservation potential of tree resin, but our observations also suggest that provenance (including any possibility that a modern resin has been thermally treated to make it appear older) should be scrutinized when single pieces with atypical thermal behavior and exceptionally well-preserved extant morphotypes come to light.
\end{abstract}

Key words: bryophyte, copal, Dominican amber, evolution, FTIR spectroscopy, melting point analysis, Macromitrium, Miocene

Jochen Heinrichs, Systematic Botany and Mycology, University of Munich (LMU), Menzinger Str. 67, 80638 Munich, Germany; e-mail: jheinrichs@lmu.de

Dale H. Vitt, Department of Plant Biology and Center for Ecology, Southern Illinois University, Carbondale, IL 62901, USA; dvitt@siu.edu

Alfons Schäfer-Verwimp, Mittlere Letten 11, 88634 Herdwangen-Schönach, Germany; moos.alfons@kabelbw.de

Eugenio Ragazzi, Department of Pharmaceutical and Pharmacological Sciences, University of Padova, Largo E. Meneghetti 2, 35131 Padova, Italy; eugenio.ragazzi@unipd.it

Giovanni Marzaro, Department of Pharmaceutical and Pharmacological Sciences, University of Padova, Via Marzolo 5, 35131 Padova, Italy; giovanni.marzaro@unipd.it

David A. Grimaldi, Division of Invertebrate Zoology, American Museum of Natural History, 79th Street at Central Park West, New York, NY 10024, USA; grimaldi@amnh.org

Paul C. Nascimbene, Division of Invertebrate Zoology, American Museum of Natural History, 79th Street at Central Park West, New York, NY 10024, USA; pnascimbene@amnh.org

Kathrin Feldberg, Systematic Botany and Mycology, University of Munich (LMU), Menzinger Str. 67, 80638 Munich, Germany; e-mail: k.feldberg@bio.lmu.de

Alexander R. Schmidt, Georg-August-Universität Göttingen, Courant Research Centre Geobiology, Goldschmidtstraße 3, 37077 Göttingen, Germany; alexander.schmidt@geo.uni-goettingen.de

\section{INTRODUCTION}

About 200 species of Cenozoic mosses have been reported from the Eocene to Pliocene epochs (Frahm 2000, 2010), of which a considerable number are preserved in the form of amber inclusions. Amber derives from various types of fossil tree resins that have been deposited in wet sediments of river deltas or lagoons (Grimaldi 1996), and this natural polymer provides an excellent medium for the preservation of small, softbodied bryophytes. Numerous mosses have been 
reported from Eocene Baltic and Ukrainian amber (Frahm 2010; Ignatov \& Perkovsky 2011), whereas amber from the Dominican Republic is the most significant source of Miocene moss fossils (Frahm \& Reese 1998; Frahm 2001, 2009).

Several mines in the northern, eastern and western parts of the Dominican Republic yield ambers with an estimated age of 15-20 million years (Iturralde-Vinent \& MacPhee 1996). Beside these ambers, copal (up to 300-years-old) is excavated from various Dominican localities (Poinar 2010). Both amber and copal were produced by trees assigned to the Fabaceae genus Hymenaea L. (Poinar 1991). Both the Miocene and more recent trees comprised floral elements of diverse tropical forests with open areas, and were rich in epiphytes (Grimaldi 1996). Until now, 28 mosses have been described from the Dominican Miocene amber forest, of which the vast majority match the morphology of extant genera or species (Frahm \& Newton 2005).

In the course of a study of plant inclusions in the amber collection at the American Museum of Natural History, we investigated a sample from the northern mines of the Dominican Republic that contains several inclusions of leafy liverworts, as well as an acrocarpous moss with sporophytes. This moss matches the morphology of the extant genus Macromitrium of the family Orthotrichaceae, which has not yet been previously recognized as a fossil. The inclusions are described and illustrated, and taxonomic affiliations are discussed. As a consequence of the unusual thermal behaviour of the resin, we conducted chemical analyses and determined its melting point.

\section{MATERIAL AND METHODS}

INVESTIGATION AND TAXONOMICAL TREATMENT OF THE INCLUSIONS

The piece of resin studied here is part of the Dominican amber collection of the American Museum of Natural History (collection number AMNH-DR-14-235). The resin specimen of $5 \times$ $2 \times 1 \mathrm{~cm}$ size has an orange to reddish color and shows numerous inclusions of bubbles and bryophytes. According to the accompanying label it originated from the northern mines of the Dominican Republic.

The resin surface was polished manually with a series of wet silicon carbide abrasive papers [grit from FEPA P $600-4000(25.8 \mu \mathrm{m}$ to $5 \mu \mathrm{m}$ particle size), firm Struers] to minimize light scattering during the investigation. The prepared specimen was placed on a glass microscope slide with a drop of water applied to the upper surface of the amber, and covered with a glass coverslip. The inclusions were studied using a Carl Zeiss AxioScope A1 compound microscope. In most instances, incident and transmitted light were used simultaneously. Oblique incident light was obtained using a goose-neck light guide 200 of a Carl Zeiss CL 1500 Eco cold light source. The images of Figs 1 and 2 are digitally-stacked photomicrographic composites obtained from several focal planes using the software package HeliconFocus 5.0.

The bryophyte inclusions were reconciled with herbarium material of extant species and relevant literature. We used a morphological-typological species concept to assign the inclusions to three taxa of bryophytes.

\section{RESIN ANALYSES}

The tip of the goose-neck light guide was initially arranged in such a way that the light was emitted at a distance of just 3-4 $\mathrm{mm}$ from the lateral surface of the amber piece. After investigation of the amber specimen for a couple of minutes, a resinous odor appeared and blistering occurred in an area of about $5 \mathrm{~mm}$ diameter, along with a darkening and development of circular fissures in the resin around this area (Fig. 1C). This thermal behavior was unexpected, since appreciable weight loss of heated mature Dominican amber starts at about $200^{\circ} \mathrm{C}$ (Ragazzi et al. 2003), and 'melting points' of amber have generally been reported between 200 and $380^{\circ} \mathrm{C}$ (Poinar 1992). The $15 \mathrm{~V} / 150 \mathrm{~W}$ halogen bulb lamp of the cold light source, however, produced only about $80^{\circ} \mathrm{C}$ at the tip of the gooseneck light guide. Blistering of resin under the heat of a cold-light source is typical for solidified extant 

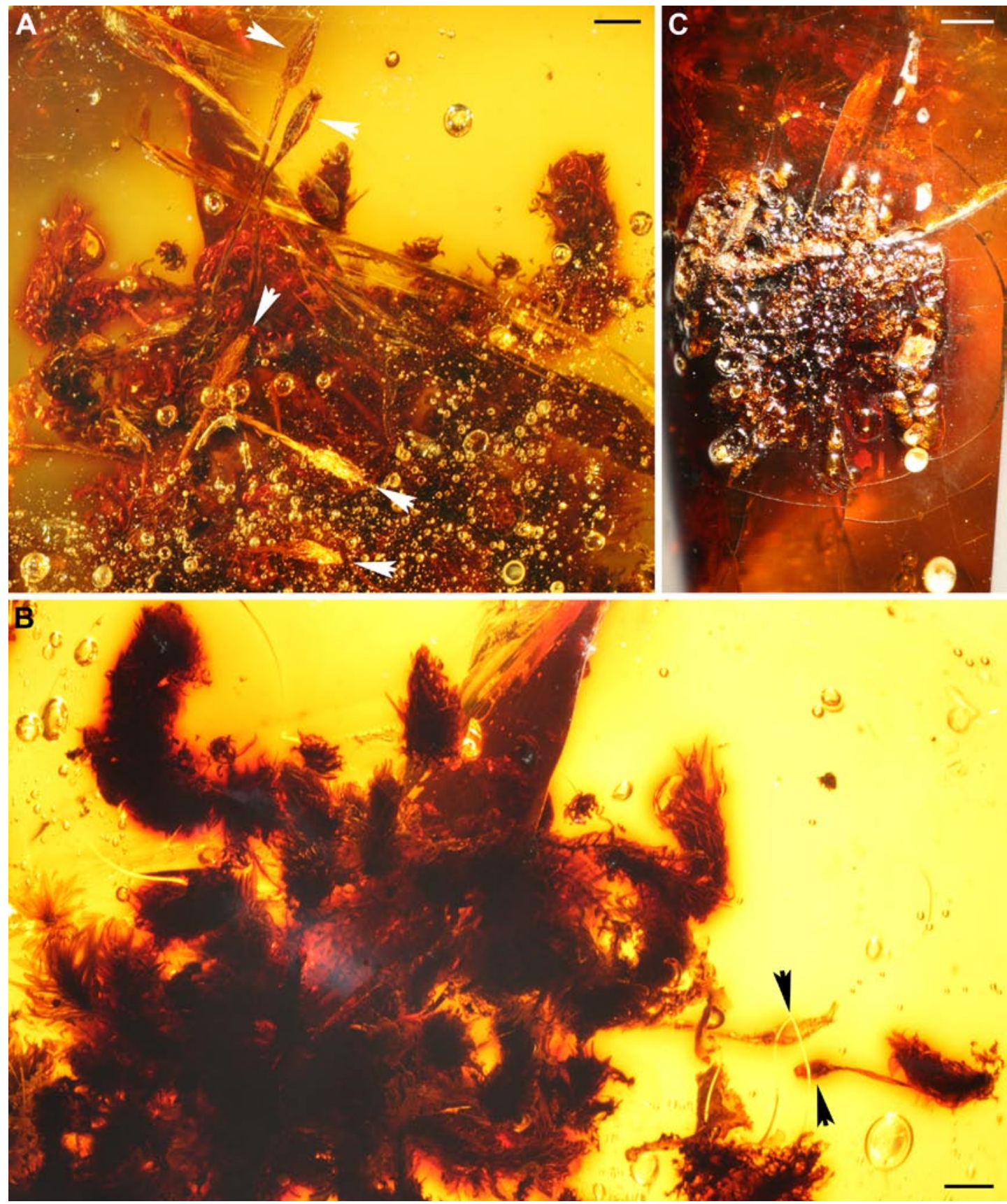

Fig. 1. A \& B - Piece of Miocene Dominican amber with inclusions of Macromitrium richardii Schwägr. (AMNH-DR-14-235). Arrowheads point to sporophytes. C - Decomposed surface of the amber piece after exposure to a cold light source. Scale bars $=1 \mathrm{~mm}$. 
resin and for some subfossil resin (copal), but not for mature amber.

As a consequence of our observations, we performed Fourier Transform Infrared Spectroscopy (FTIR) analyses on a separated fragment of the specimen to further elucidate whether the specimen represents Miocene amber or a more recent resin. FTIR is a standard procedure for a general characterization of extant and fossil resins (Beck et al. 1964; Langenheim \& Beck 1965). FTIR analysis was performed on the freshly powdered specimen, dispersed in a potassium bromide pellet using a Perkin Elmer 1600 Series FTIR Spectrophotometer (Perkin Elmer, Monza, Italy) with a wavelength range of $2-15 \mu \mathrm{m}\left(5000-670 \mathrm{~cm}^{-1}\right)$ (transmittance mode). Solubility of the resin in organic solvents was determined by exposing the specimen to a small drop of solvent (acetone) for $30 \mathrm{~s}$, and looking for any dissolution of the surface (Roghi et al. 2006). The melting point of a small amount of the pulverized resin was determined using a Gallenkamp MFB-595-010M open capillary tube apparatus (Weiss Gallenkamp, London, UK), operating from room temperature to $300^{\circ} \mathrm{C}$.

\section{RESULTS}

THE MOSS INCLUSIONS - MACROMITRIUM RICHARDII

The most dominant inclusions are several leafy shoots of an acrocarpous moss with 10 sporophytes and over 20 further remains of setae. Young sporophytes are still covered by calyptrae (Fig. 2A, B) whereas old, degraded ones allowed for insights into capsule wall and peristome structure (Fig. $2 \mathrm{C}-\mathrm{E}$ ). As a result of an initial grinding in the context of the jewelry making process, several near-surface leaves had been partially abscised, allowing for an inspection of the leaf cross section (Fig. 2J).

The moss inclusions are described as follows: Gametophyte - Plants slender, forming a rustybrown mat with creeping stems producing numerous ascending to erect, simple or forked, 3-6 mm tall branches. Leaves partly crisped and enrolled, partly spreading, ca $1.0-1.7 \times 0.20$ $0.26 \mathrm{~mm}$, keeled, lanceolate, obtusely mucronate; margins entire to indistinctly crenulate due to projecting cells, plane or lower $3 / 4$ slightly reflexed; costa simple, narrow, ending in apex, dorsally consisting of elongate, smooth cells, in transverse section $c a 2$ cells thick; lamina in transverse section 1-layered, upper cells irregularly hexagonal to rounded-elliptic or slightly elongate, with thick walls, ca 7-12 $\mu \mathrm{m}$ wide, bulging, unipapillose, single ones pluripapillose, cells towards leaf center and base often somewhat elongate, basal cells \pm smooth. Perigonia not observed. Perichaetial leaves not greatly differentiated. Sporophyte Setae (3-)5-7 mm long, smooth. Capsules ovoid, becoming narrowly ovoid to ovoid-oblong when old (and dry?), 600-1400 × 350-450 $\mu \mathrm{m}, \pm 8$-plicate, consisting of rather thin-walled, hexagonal to shortly elongate cells; stomata possibly present in basal third; peristome single, badly preserved or degraded, possibly consisting of 16 teeth. Calyptrae covering the entire capsule, with many smooth hairs consisting of ca 10-14 cells.

The distinguishable morphological character states of the moss inclusions are in accordance with the current concept of the extant Neotropical species Macromitrium richardii Schwägr.

\section{SYNINCLUSIONS - LIVERWORTS CHEILOLEJEUNEA} ANTIQUA AND FRULLANIA SP.

Between the Macromitrium gametophytes we recognized a few, partly degraded branches of a holostipous Lejeuneaceae with a 3-cell wide stem and large, rotundate underleaves. The incubously inserted, entire-margined leaves had rounded lobes and large lobules with strongly arched keels and a short tooth on the free margin. Morphologically, the gametophytes resemble the extinct Dominican amber species Cheilolejeunea antiqua (Grolle) W. Ye \& R. L. Zhu. We also observed a few branched, strongly degraded shoot fragments of a Frullania species with bifid underleaves and leaves whose slender lobules were inserted in some distance to the shoots, corresponding to the current concept of Frullania subg. Diastaloba (Spruce) Kamim. 

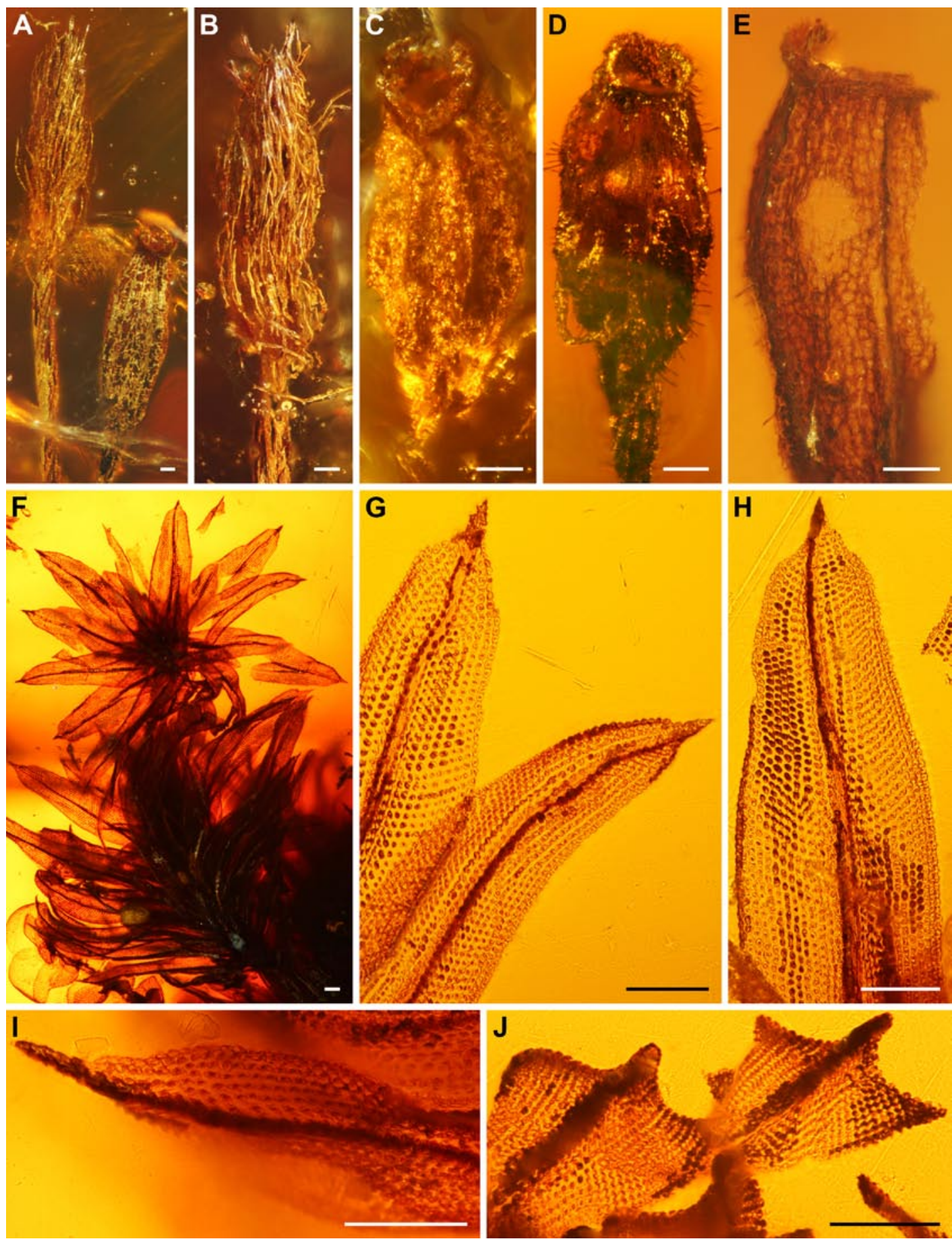

Fig. 2. Macromitrium richardii Schwägr. in a piece of Dominican amber (AMNH-DR-14-235). A - Young sporophyte with capsule covered by calyptra (left) and old capsule (right). B - Young capsule covered by calyptra. C-E - Old capsules. $\mathrm{F}-\mathrm{I}-$ Leaves, surface view. J - Leaves, cross section. Scale bars $=100 \mu \mathrm{m}$. 


\section{FEATURES OF THE RESIN SAMPLE}

The main features of the FTIR spectrum obtained from the separated resin piece (Fig. 3) are summarized in Table 1. They corresponded to reference spectra of Dominican amber. The acetone test (applied to the surface for $30 \mathrm{~s}$ ) did not produce any appreciable dissolution of the resin. The resin did

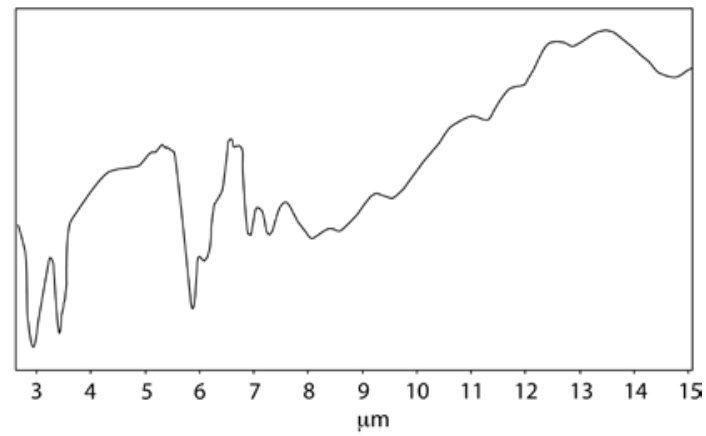

Fig. 3. Solid-state FTIR spectrum of the amber specimen AMNH-DR-14-235.

not become tacky, nor did it show any alteration of the surface. Under UV light (365 nm), the resin exhibited a slight yellowish-green fluorescence. Below $250^{\circ} \mathrm{C}$, no appreciable melting of the pulverized resin was detectable; however, starting at $250^{\circ} \mathrm{C}$, an evident browning phenomenon occurred, with transition of the baseline yellow color of the pulverized resin to light reddish $\left(250^{\circ} \mathrm{C}\right)$ and ultimately dark brown $\left(300^{\circ} \mathrm{C}\right.$, see Fig. 4).

\section{DISCUSSION}

\section{AMBER OR COPAL?}

The blistering at the surface of the amber piece during inspection under a 'cold' light source was surprising considering the typically higher melting point of amber, and this suggested the possible presence of a piece of subfossil copal rather than of fossil amber. Dominican copal is much younger than the ambers from this region and has an age of at best a few hundred years (Poinar 2010).

The age of the studied resin is crucial for the interpretation of the bryophyte inclusions and the reconstruction of their evolutionary history (Heinrichs et al. 2009b).

The negative 'acetone test' strongly argues for a mature rather than a young resin, which would have been dissolved very easily by the solvent. However, copal is sometimes cooked to clarify it, or to give it an older 'amber-like' appearance. To exclude the possibility of an artifically thermally treated resin, we conducted additional analyses.

Table 1. Main FTIR spectrum features of the specimen.

\begin{tabular}{|c|c|c|c|c|}
\hline $\begin{array}{l}\text { Functional } \\
\text { group }\end{array}$ & $\begin{array}{l}\text { Band, wave } \\
\text { length }[\mu \mathrm{m}]\end{array}$ & $\begin{array}{l}\text { Band, wave } \\
\text { number }\left[\mathrm{cm}^{-1}\right]\end{array}$ & Intensity & Assignment \\
\hline$-\mathrm{O}-\mathrm{H}$ & 2.90 & 3448 & strong & $\mathrm{O}-\mathrm{H}$ stretching \\
\hline \multirow{4}{*}{$-\mathrm{CH}_{2}-\mathrm{CH}_{3}$} & 3.50 & 2857 & strong & Stretching of C-H bonds \\
\hline & 6.90 & 1449 & medium & Scissoring and bending of $\mathrm{C}-\mathrm{H}$ bonds \\
\hline & 7.30 & 1370 & medium & Bending of $\mathrm{C}-\mathrm{H}$ bonds \\
\hline & 11.30 & 885 & weak & $\begin{array}{l}\mathrm{C}=\mathrm{CH}_{2} \text { : exocyclic methylene out-of-plane defor- } \\
\text { mation (bending) }\end{array}$ \\
\hline$-\mathrm{C}=\mathrm{O}$ & 5.85 & 1709 & medium & Stretching of $\mathrm{C}=\mathrm{O}$ double bonds \\
\hline \multirow[t]{4}{*}{$-\mathrm{C}-\mathrm{O}-$} & 8.10 & 1235 & weak & Absorption of C-O single bonds (acids) \\
\hline & 8.60 & 1163 & weak & Absorption of C-O single bonds \\
\hline & 9.50 & 1053 & weak & Absorption of C-O single bonds (alcohol) \\
\hline & 14.60 & 685 & medium/weak & Possibly $\mathrm{OH}$ out-of-plane bending, alcohol \\
\hline $\mathrm{C}=\mathrm{C}$ & 6.10 & 1639 & weak & $\mathrm{C}=\mathrm{C}$ stretching \\
\hline$-\mathrm{C}-\mathrm{H}$ aromatic & 12.00 & 833 & weak & Out-of-plane bending of aromatic C-H \\
\hline
\end{tabular}




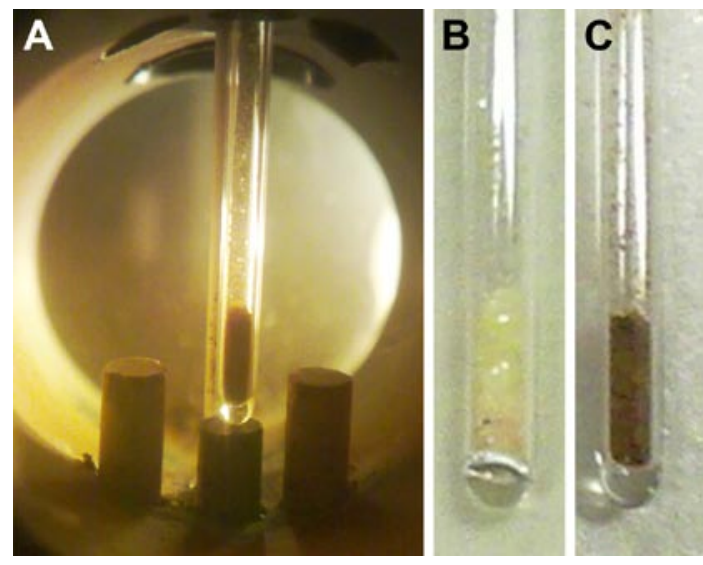

Fig. 4. Appearance of the powdered sample inside a thin glass tube in the melting point apparatus (A). For a direct comparison of the color after exposure to different temperatures, the two rightmost images show the aspect of the powdered sample at room temperature (B), and after heating at $250^{\circ} \mathrm{C}$ (C), respectively.

\section{FOURIER TRANSFORM INFRARED SPECTROSCOPY}

FTIR absorption bands arise through stretching and bending vibrations of functional groups. The absorption bands in the region 2.5-8 $\mu \mathrm{m}(4000$ $1250 \mathrm{~cm}^{-1}$ ) (Fig. 3) commonly occur in fossil resins and are of little interest for proofs of origin (Langenheim \& Beck 1965). However, at higher wavelengths, especially in the region $8-10 \mu \mathrm{m}$ (1250-1000 $\left.\mathrm{cm}^{-1}\right)$, the skeletal vibrations point to the chemical nature of main resin constituents and thus have a high diagnostic value. The small absorption bands at 8.1 and $8.6 \mu \mathrm{m}$ correspond well to FTIR reference spectra of Dominican amber (Langenheim \& Beck 1968; Villanueva-García et al. 2005). The low amplitude of the absorption band close to $11.3 \mu \mathrm{m}$ resembles the so-called Type II Dominican Republic amber (Langenheim \& Beck 1965), referred to as coming from Palo Quemado, Cordillera Septentrional. Type I Dominican amber originates from Palo Alto de la Cumbre and has a stronger band at $11.3 \mu \mathrm{m}$ (Langenheim \& Beck 1968; Henwood 1992).

Despite the extensive similarity of the FTIR spectra between our specimen and Type II Dominican amber, the FTIR analyses do not reject the alternative hypothesis of a piece of Dominican
Cotui copal that was artificially thermally treated. Theoretically, heating of copal can produce changes in the composition of the resin, and it may cause alterations such as the loss of some absorption bands, e.g., that around $11 \mu \mathrm{m}$. Given that the original resin piece possessed a pronounced $11 \mu \mathrm{m}$ band, but lost that feature through accelerated oxidation, the FTIR spectrum will not differ from those derived from genuine amber. Hence, a non-natural process of 'maturation' through heating cannot be distinguished from the natural amberization process using FTIR spectra. However, our additional analyses (see following sections) cast doubt on the hypothesis of a thermally treated piece of copal and support the presence of genuine Dominican amber.

\section{ABIOTIC INCLUSIONS OF THE RESIN, FLUORESCENCE AND MELTING POINT ANALYSES}

Fossil or subfossil resins are sometimes heated to make them more transparent. This procedure commonly leads to the disappearance of embedded water and air bubbles, making the classical aspect of fine radial cracks, also named 'sun-spangles' (Grimaldi 1996, p. 133). In the present sample, such artifacts are lacking, but several embedded bubbles are visible (Fig. 1). Another point to be considered in favor of this being a piece of genuine amber is its fluorescence under UV light, that most probably would have disappeared in a case of artificial heating.

The melting point analyses demonstrated that the resin did not melt during heating to $300^{\circ} \mathrm{C}$. Instead the resin decomposed in accordance with the classical curve of thermal gravimetric analysis and differential thermal gravimetric analysis of amber (Ragazzi et al. 2003). This behavior can be ascribed to the polymeric complex composition of the amber, whose molecular structure does not permit it to melt, but does allow it to succumb to degradative processes such as formation of quinones (dark colored) and decarboxylative reactions with carbon dioxide release. Decomposition of amber may take place not only by means of heat application, but also as a consequence of a photochemical decarboxylation reaction, following the absorption of light energy by the molecules. This hypothesis can explain both the blistering 
phenomenon and the browning of the amber surface seen after cold light application for microscopy observation (Fig. 1C).

\section{COLOR AND PUTATIVE ORIGIN}

Another relevant clue for the identity of the resin is the 'North mines' provenance indicated on the specimen's label. Both Palo Quemado and Palo Alto amber mines are located in the Cordillera Septentrional in the north of the Dominican Republic; however, the Palo Quemado area is farther north than Palo Alto. Cotui copal comes from a valley between the Cordillera Septentrional and the Cordillera Central (Poinar 1992). The amber from Palo Quemado is generally more oxidized than the amber from Palo Alto (Poinar 1992) and appears as a red to yellow, occasionally blue amber; amber from Palo Alto is generally clear, with a yellow to red color. The orange-red, rather dark resin piece under study fits well within the color spectrum exhibited by amber from the northern mines. In contrast, Cotui copal is whitish in color to pale yellow, and when it ages the surface deeply crazes but darkens only slightly to a deeper shade of yellow.

\section{LIVERWORT INCLUSIONS}

The syninclusions of Macromitrium richardii are suboptimally preserved; however, the visible features are in good accordance with two taxa that have previously been reported from Dominican amber. The extinct species Cheilolejeunea antiqua is known only from inclusions in Dominican amber (Grolle 1983, as Leucolejeunea antiqua Grolle), and provides further support that the resin is a piece of genuine Dominican amber. Frullania subg. Diastaloba morphotypes (gametophytes whose leaf lobules are inserted in some distance to the stem) have likewise been reported from Dominican amber (Heinrichs \& Schmidt 2010), but also occur in the modern Dominican Republic.

\section{CONCLUSION ON THE IDENTITY OF THE \\ INVESTIGATED RESIN AND PROPOSALS \\ FOR FURTHER INVESTIGATION}

We present several lines of evidence for the presence of genuine Dominican amber despite the unexpected blistering of the specimen when exposed to a cold-light source. The chemical analysis of this resin piece, as well as its behavior after heating to $300^{\circ} \mathrm{C}$, indicate typical characters of Dominican amber and support its being a sample of amber from Palo Quemado that has some outlier properties. Besides substantiating the presence of genuine amber, our findings may also lead to a very practical suggestion: that in some cases, the application of even a cold light source to an amber sample may produce appreciable damage (see Fig. 1C), possibly compromising or destroying an inclusion that lies just beneath the amber surface. Thus the common practice of embedding precious amber samples in a high-grade epoxy resin for safer and long-term conservation (Nascimbene \& Silverstein 2001) may also offer an effective shield against the observed photodegradation event.

\section{ASSIGNMENT OF THE MOSS INCLUSION} TO AN EXTANT SPECIES

Using a morphological-typological species concept and considering evidence both from gametophytes and sporophytes, the moss inclusions fit the extant species Macromitrium richardii, a widespread Neotropical representative of Orthotrichaceae that also occurs in the Gulf Coastal Plain of eastern United States (Vitt 1994). Considering the epiphytic nature of many Orthotrichaceae, their sparse fossil record is surprising. Finding an amber inclusion that is morphologically indistinguishable from an extant species raises questions about the longevity of species and the reliability of the taxonomic treatment. Even when exceptionally well-preserved amber inclusions become available, they hardly show all characters of putative extant relatives. In the present study we were not able to investigate details of the capsule, including peristome structure, spores and distribution of stomata, or cross sections of the stem. We also need to point out that morphological and phylogenetical species concepts are not necessarily congruent, especially since molecular studies point to extensive morphological homoplasy in bryophyte lineages and the presence of numerous morphologically cryptic or near-cryptic species (Hedenäs \& Eldenäs 2007; 
Wachowiak et al. 2007; Heinrichs et al. 2010, 2011; Carter 2012). Currently a wide morphological species concept is adopted for Macromitrium richardii, and morphotypes with sparsely to densely pilose calyptrae are included in this taxon. Medina et al. (2012) demonstrated that the inclusion of molecular data in revisionary studies may lead to the adoption of narrow species concepts in the Orthotrichaceae; however, such data are not yet available for M. richardii. A comprehensive molecular dataset of Macromitrium species and related lineages would enable us to estimate divergence times for Orthotrichaceae; the circumscription and position of $M$. richardii would be crucial for this study. Amber fossils of bryophytes are increasingly used to calibrate molecular trees (Hartmann et al. 2006; Heinrichs et al. 2007, 2009b; Wilson et al. 2007; Cooper et al. 2012); however, Feldberg et al. (2013) demonstrated the potential impact of fossil constraints while highlighting the need to carefully assess the assignment of fossils to prevent misleading results. A reciprocal illumination approach comparing the age estimates obtained by analyses with and without the Macromitrium constraint under question may allow us to weigh the pros and contras of our actual assignment of the moss inclusions to an extant species.

\section{CONCLUDING REMARKS}

Our inclusions demonstrate the exceptional preservational properties of tree resin, but our observations also suggest that provenance (including any possibility that a modern resin has been thermally treated to make it appear older) should be scrutinized when single pieces with atypical thermal behavior and exceptionally well-preserved extant morphotypes come to light. We also need to stress that morphology-based assignments of fossils to extant species have a certain probability of error which can be reduced by considering evidence from DNA sequence variation of related species.

AcKnowledgements. We thank Michael S. Engel (Lawrence) for discussion. This is publication number 116 from the Courant Research Centre Geobiology that is funded by the German Excellence Initiative.

\section{REFERENCES}

Beck C. W., Wilbur E. \& Meret S. 1964. Infra-red spectra and the origin of amber. Nature 201(491): 256-257.

CARTER B. E. 2012. Species delimitation and cryptic diversity in the moss genus Scleropodium (Brachytheciaceae). Molec. Phylogenet. Evol. 63(3): 891-903.

Cooper E. E., Henwood M. J. \& Brown E. A. 2012. Are the liverworts really that old? Cretaceous origins and Cenozoic diversifications in Lepidoziaceae reflect a recurrent theme in liverwort evolution. Biol. J. Linn. Soc. 107(2): 425-441.

Feldberg K., Heinrichs J., Schmidt A. R., VÁŇA J. \& SCHNEIDER H. 2013. Exploring the impact of fossil constraints on the divergence time estimates of derived liverworts. Pl. Syst. Evol. 299(3): 585-601.

FRAHM J.-P. 2000. Neue Laubmoosfunde aus baltischem Bernstein. Cryptog. Bryol. 21(2): 121-132.

FRAHM J.-P. 2001. New records of mosses from Dominican amber. Trop. Bryol. 20: 39-42.

FRAHM J.-P. 2009. The first record of Sphagnum from the Tertiary in Baltic amber and other new records of mosses from Baltic and Dominican amber. Cryptog. Bryol. 30(2): 259-263.

FRAHM J.-P. 2010. Die Laubmoosflora des baltischen Bernsteinwaldes Wiessdorn, Jena.

FrahM J.-P. \& NEWTON A. E. 2005. A new contribution to the moss flora of Dominican amber. Bryologist 108(4): 526-536.

FRAHM J.-P. \& REESE W. D. 1998. Calymperes palisotii (Musci; Calymperaceae) found in Dominican amber. Bryologist 101(1): 131-132.

GRIMALDI D. A. 1996. Amber: window to the past. Harry N. Abrams, Inc., New York.

GROLLE R. 1983. Leucolejeunea antiqua n. sp., das erste Lebermoos aus Dominikanischem Bernstein. Stuttgarter Beitr. Naturk., B. 96: 1-9.

HARTMANn F. A., Wilson R., GRAdSTEIN S. R., SCHNEIDER H. \& HEINRICHS J. 2006. Testing hypotheses on species delimitations and disjunctions in the liverwort Bryopteris (Jungermanniopsida: Lejeuneaceae). Int. J. Pl. Sci. 167(6): 1205-1214.

HEDENÄS L. \& EldENÄS P. 2007. Cryptic speciation, habitat differentiation, and geography in Hamatocaulis vernicosus (Calliergonaceae, Bryophyta). Pl. Syst. Evol. 268(1-4): 131-145.

HeinRichs J. \& SCHMIDT A. R. 2010. An inclusion of Frullania subg. Diastaloba s. 1. (Frullaniaceae, Porellales) in Dominican amber. Trop. Bryol. 31: 91-94.

Heinrichs J., Klugmann F., Hentschel J. \& SchneIDER H. 2009a. DNA taxonomy, cryptic speciation and 
diversification of the Neotropical-African liverwort, Marchesinia brachiata (Lejeuneaceae, Porellales). Molec. Phylogenet. Evol. 53(1): 113-121.

Heinrichs J., Hentschel J., Feldberg K., Bombosch A. \& SCHNEIDER H. 2009b. Phylogenetic biogeography and taxonomy of disjunctly distributed bryophytes. J. Syst. Evol. 47(5): 497-508.

Heinrichs J., Hentschel J., Wilson R., FeldberG K. \& SCHNEIDER H. 2007. Evolution of leafy liverworts (Jungermanniidae, Marchantiophyta): estimating divergence times from chloroplast DNA sequences using penalized likelihood with integrated fossil evidence. Taxon 56(1): 31-44.

Heinrichs J., Kreier H.-P., FeldBerg K., Schmidt A. R., Zhu R. L., Shaw B., Shaw A. J. \& Wissemann V. 2011. Formalizing morphologically cryptic biological entities: New insights from DNA taxonomy, hybridization, and biogeography in the leafy liverwort Porella platyphylla (Jungermanniopsida, Porellales). Amer. J. Bot. 98(8): 1252-1262.

Heinrichs J., Hentschel J., Bombosch A., Fiebig A., REISE J., EdELMANN M., KREIER H.-P., SCHÄFER-VERWIMP A., CASPARI S., SCHMIDT A.R., ZHU R.-L., VON KonRat M., ShaW B. \& SHAW A. J. 2010. One species or at least eight? Delimitation and distribution of Frullania tamarisci (L.) Dumort. (Jungermanniopsida, Porellales) inferred from nuclear and chloroplast DNA markers. Molec. Phylogenet. Evol. 56(3): 1105-1114.

HENWOOD A. 1992. Exceptional preservation of Dipteran flight muscle and the taphonomy of insects in amber. Palaios 7: 203-212.

Ignatov M. S. \& PERKovsky E. E. 2011. Mosses from Rovno amber (Ukraine). Arctoa 20: 1-18.

IturRalde-Vinent M. \& MacPheE R. D. E. 1996. Age and paleogeographical origin of Dominican amber. Science 273(5283): 1850-1852.

LANGENHEIM J. H. \& BECK C. W. 1965. Infrared spectra as a means of determining botanical sources of amber. Science 149(3679): 52-55.

LANGenheim J. H. \& BeCK C. W. 1968. Catalogue of infrared spectra of fossil resins (ambers): I. North and South America. Bot. Mus. Leafl. 22: 65-120.
Medina R., Lara F., Goffinet B., Garilleti R. \& MAZIMPAKA V. 2012. Integrative taxonomy successfully resolves the pseudo-cryptic complex of the disjunct epiphytic moss Orthotrichum consimile s.1. (Orthotrichaceae). Taxon 61(6): 1180-1198.

NASCimBene P. \& Silverstein H. 2001. The preparation of fragile Cretaceous ambers for conservation and study of organismal inclusions. In: D. GRIMALDI (ed.), Studies on Fossils in Amber, with Particular Reference to the Cretaceous of New Jersey, pp. 93-102. Backhuys Publishers, Leiden, The Netherlands.

PoINAR G. O. Jr. 1991. Hymenaea protera sp. n. (Leguminosae, Caesalpinioideae) from Dominican amber has African affinities. Experientia 47: 1075-1082.

PoINAR G. O. Jr. 1992. Life in amber. Stanford University Press, Stanford.

POINAR G. O. Jr. 2010. Palaeoecological perspectives in Dominican amber. Annales de la Societe Entomologique de France (n.s.) 46(1-2): 23-55.

Ragazzi E., Roghi G., Giaretta A. \& Gianolla P. 2003. Classification of amber based on thermal analysis. Thermochimica Acta 404: 43-54.

Roghi G., Ragazzi E. \& Gianolla P. 2006. Triassic amber of the Southern Alps (Italy). Palaios 21: 143-154.

VillanUEVA-García M., MartíneZ-Richa A. \& RoBles J. 2005. Assignment of vibrational spectra of labdatriene derivatives and ambers: a combined experimental and density functional theoretical study. ARKIVOC 2005(6): 449-458.

VITT D. H. 1994. Orthotrichaceae. In: A. J. SHARP., H. CRUM, P. M. ECKEL (eds), The moss flora of Mexico. Mem. New York Bot. Gard. 69: 590-656.

WACHOWIAK W., BĄCZKIEWICZ A., CHUDZIŃSKA E. \& BUCZKOWSKA K. 2007. Cryptic speciation in liverworts - a case study in the Aneura pinguis complex. Bot. J. Linn. Soc. 155(2): 273-282.

Wilson R., HEINRICHS J., HENTSCHEL J., GRADSTEIN S. R. \& SCHNEIDER H. 2007. Steady diversification of derived liverworts under Tertiary climatic fluctuations. Biological Letters 3(5): 566-569. 